16. Liri, P. (2018). A house divided: The Murreys of the border and the nice and decline of a small Irish house. History workshop journal, vol. 86, autumn, pp. 269-290.

17. Macdonald, $S$. (2017). Counting witches: illuminated and distorting the shape of witcheraft in Scotland. Journal of Scottish historical studies, vol. 37, issue 1, pp. 1-18.

18. Mutch, A. (2015). Religion and national identity: governing Scottish Presbyterianism of the eighteenth century. Edinburg: Edinburg University Press, 264 p.

19. Peak, I. (2019). A chronology of some memorable assiduities: the representation of the recent past in English almanacs 1648-1660. Historical research journal, vol. 92, issue 255, pp. 97-117.

20. Peres, E. (2018). Colonial intimate's kinship sexuality and marriage in Southern California, 1769-1885. Before gold California under Spain and Mexica. Norman: University of Oklahoma, $396 \mathrm{p}$.

21. Poper, M., Duffert R. (2018). Family legacies in the centenary: motives First World war commemoration among British and German descendants. History and memory journal, vol.30, no. 1. pp. 76-115.

22. Rojer, J. (2015). The hero building: an architecture of Scottish national identity. Farnham: Ashgate Publishing Limited, $227 \mathrm{p}$.

23. Sangha, L. (2018). The social, personal and spiritual dynamics of ghost stories in early modern England / L. Sangha // https: doi org / 10.1017 / soo 18246 X 1800047X

24. Scottish women a documentary history, 1780-1914 (2013). Ed. E. Breitenbach, C. Fleming. Edinburg: Edinburg University Press, 340 p.

25. Soares, C. (2018). Leaving the Victorian children's institutions: aftercare, friendship and support / C. Soares // https: // doi. Org 10. 1093 / hws/ db2 001.

26. Swinfen, D. (2018) Moncrif: the life and career of James Wichwood Moncrif, 1811-1895. Brought Ferry: Shakenoak Press, 297 p.

Received 08.09.2020

Accepted 18.09.2020

DOI: $10.15421 / 272019$

УДК 159.9.019.4

\title{
А. Макарова
}

Житомирський державний університет імені Івана Франка, м. Житомир, Україна

\section{КАТЕГОРІАЛЬНИЙ АПАРАТ АРХЕТИПНОГО ПІДХОДУ: СОЦІАЛЬНО-ФІЛОСОФСЬКИЙ АСПЕКТ}

\author{
E-mail: Makarova AO@ukr.net
}

ORCID: 0000-0001-7270-0135

Анотація. Розглянуто категорії та поняття, що складають методологічну основу сучасного філософського підходу до соціокультурних явищ - архетипного. Постульовано його цінність як методологічного інструменту аналізу соціальної реальності, наголошено на перспективності його використання у соціогуманітарній науці. Зосереджено увагу на широті його методологічної палітри, що зумовлено мультидисциплінарним потенціалом цього підходу. Висвітлено нюанси термінологічного дискурсу, що розгортаються в межах розробки положень аретипного підходу у сучасній гуманітарній науці в Україні, і не лише у філософській, а й у соціокультурологічній науці. Виокремлено завдання класифікації архетипів як базової ланки семантичного конструювання методологічного підходу.

Як найбільш артикульоване, проаналізовано поняття «архетип»; наведено приклади, які використані дослідниками для віднесення того чи іншого архетипу до певної категорії, здійснено співставлення поняття «архетип» із категоріями, через які найчастіше деталізуються моделі архетипного аналізу. Серед категорій, з якими пов'язується архетип 
як методологічний конструкт, акцентовано поняття «символ», «міф», «образ («архетипний образ»), «архетипний смисл», «ідея», «концепт». «паттерн». Розкрито зміст деяких суперечливих моментів у масиві архетипного аналізу, пов'язаних із термінологічною невизначеністю.

Наприкінці здійснено огляд проблематики, в якій архетипний підхід виявляється плідним, особливий акцент зроблено на соціальних проблемах, пов'язаних із сферою аналізу діяльності та соціальних практик. Запропоновано критерії, за якими можна здійснити чіткіше розмежування поняття «архетип» та суміжних категорій архетипного підходу. Підкреслено значення архетипу як підгрунтя соціальної практики, висловлено припущення про соціальну природу психологічного архетипу із потенційним виходом у соціальну філософію, а не у культурологію чи етнопсихологію. На думку автора, саме цей аспект архетипного підходу потребує подальшого унормування, або віднесення «фігуративних» архетипів до образів (тоді увиразнюється роль символу), а до категорій архетипів слід віднести ті складові детермінації людської діяльності, які, будучи і досі «замкненими» у сфері антропології та теорії культури, не мають адекватного виходу у методологію соціальної філософії - сутнісні сили людини: «дух», «душа», «розум», «розсудок», «воля», «тіло».

Ключові слова: архетип, архетипний підхід, категорійний апарат, соціально-філософський аналіз, «архетипний образ», «архетипний смисл».

\title{
A. Makarova
}

\section{Zhytomyr Ivan Franko State Universiy, Zhytomyr, Ukraine}

\section{THE ARCHETYPICAL APPROACH CATEGORIAL APPARATUS: SOCIO-PHILOSOPHICAL ASPECT}

\begin{abstract}
The article is devoted to the review of categories and concepts that form the methodological basis of the modern philosophical approach to socio-cultural phenomena - archetypal. Its value is postulated as a methodological tool for the analysis of social reality, the prospects of its use in socio-humanitarian science are emphasized. The focus is on the breadth of its methodological palette, which is due to the multidisciplinary potential of this approach. The nuances of terminological discourse, which unfold within the framework of developing the provisions of this approach in modern humanities in Ukraine and abroad, and not only in philosophical but also in socio-cultural science, are highlighted. The problem of classification of archetypes as a basic link of semantic construction of methodological approach is singled out. As the most articulated by researchers, the concept of «archetype» is singled out and analyzed; examples are given, which are used by researchers to assign this or that archetype to a certain category, the concept of «archetype» is compared with the categories through which the models of archetypal analysis are most often detailed. Among the categories with which the archetype is most often associated as a methodological construct, the concepts of «symbol», «myth», «image» («archetypal image»), «archetypal meaning», «idea», «concept» are emphasized. «Pattern». The content of some contradictory points in the array of archetypal analysis related to terminological uncertainty is revealed.

At the end, there is a review of issues in which the archetypal approach is fruitful, with special emphasis on social issues related to the analysis of activities and social practices. Criteria for proposing a clearer distinction between the concept of «archetype» and related categories of the archetypal approach are proposed. The importance of the archetype as a basis of social practice is emphasized, assumptions are made about the social nature of the psychological archetype with a potential access to social philosophy, and not to culturology or ethnopsychology. According to the author, this aspect of the archetypal approach requires further normalization, or attribution of «figurative» archetypes to images (then emphasizes the role of the symbol), and the categories of archetypes should include those though, components of the determination of human activity, which are still «closed» in spheres of anthropology and theory of culture, do not have an adequate access to the methodology of social philosophy - the essential forces of man: «spirit», «soul», «mind», «reason», «will», «body».
\end{abstract}

Keywords: archetype, archetypal approach, category apparatus, sociohilosohical analysis, «archetypal image», «archetypal meaning». 
Вступ. Науковий аналіз передбачає поєднання кількох, іноді навіть суперечливих, підходів у дослідженні одного явища. Власне науковий підхід як інтеграція ідеї, гіпотези, теорії та практики - і у соціогуманітарних науках має велике значення у будь-якому елементі свого конституювання. Особливо це відчутно, коли дослідник застосовує у своїй логіці поняття, категорії, концепти, які все ще мають відбиток репутації «відсутньої структури». 3 іншого боку, такі «прогалини» активно заповнюються науковими дискусіями, доробками, практиками, створюючи ту саму актуальність, яка потенційно здатна відповісти на «виклики часу» при «належному доопрацюванні». Подібна ситуація в науковому дискурсі склалася на початку XXI ст. стосовно архетипного підходу. Ця ситуація описується доктором філологічних наук Н. Лисюк так: «Ставлення вітчизняних учених до концепції архетипів коливається в широкому діапазоні - від жорстко обумовленої позитивістською ідеологією та відповідним «вихованням» негоції або підозри-недовіри до безсумнівно захопленого сприйняття в ролі останнього слова істини... Але і ставлення зарубіжних учених до згаданої теорії аж ніяк не однозначне. Критики психоаналітичної теорії закидають її основоположнику К. -Г. Юнгу необгрунтованість і ненауковість, а подеколи їі просто звинувачують у чистих вигадках та суб'єктивізмі, доводячи, що його теорія «не є вираженою в науковій формі», а отже, не може бути «предметом наукового доказу або спростування» [14, c. 263]. Очевидно, актуальною постає потреба «уструнчити» методологічний каркас архетипного підходу таким чином, щоб зробити його не просто звучним, а валідним при дослідженні соціокультурних явищ (наприклад, ідентичності), малих і великих соціальних структур (наприклад, етносів), механізмів і закономірностей окремих видів діяльності (наприклад, педагогічної, економічної, політичної, правової, релігійної та інших).

Об’єктом нашого аналізу є категоріальний апарат архетипного підходу як інструменту філософського пізнання. Предметом є особливості тлумачення категорій архетипного підходу у різних галузях соціогуманітарного знання, проте із акцентом на перспективах його залучення до соціально-філософських досліджень.

Метою статті є довести наукову валідність архетипного підходу як методологічної бази сучасного гуманітарного аналізу соціокультурних явищ, зокрема, соціальнофілософського, на підставі специфіки його категоріального апарату.

Незважаючи на вищезгадану «недовіру», дослідження архетипів, у тому числі і вироблення конкретних методик на основі архетипного підходу, в сучасній Україні якраз розвиваються, а не занепадають внаслідок категоріальної невизначеності. Так, якісний методологічний дискурс 3 приводу категоризації архетипного підходу відбувається вже майже десятиліття у межах діяльності «Української школи архетипіки». Серед iї методичних розробок - «Проективна тестова «Методика колірних уподобань» («Веселка») (Е. Афонін, 1987 р.), «Особистісний опитувальник «БАД» (Бурлачук, Афонін, Донченко, 2002 р.), «Тестова методика «Публічне управління» (Е. Афонін, О. Балакірєва, В. Кириченко, 2015 р.) [18]. «УША» відзначилась вагомими науковими публікаціями у галузі філософії архетипу, архетипного аналізу соціальної дійсності у різних її проявах (Е. Афонін, А. Мартинов, Т. Плахтій та інші). Це стало можливим якраз завдяки розширенню кола тлумачення терміна «архетип», трансформації його значення із вузькопсихологічної категорії до категорії загальнокультурного дискурсу, пов'язаного $з$ філософськими концептами дослідження людських практик. Так, один із засновників «УША», проф. С. Кримський у 2002 р. визначив архетипи як «наскрізні - символічні структури історії культури, що асоціюють певний тематичний матеріал свідомого та підсвідомого функціонування людських цінностей» [2, с. 39]. Наголосимо, що і в Україні, і за ії межами дослідження за методологією архетипного підходу активно проводились і до цього. Однією з перших почала досліджувати проблематику соціального та соцієтального у проекції архетипного моделювання проф. О. Донченко, співавтор монографії «Архетипи соціального життя і політика: Глибинні регулятиви психополітичного повсякдення» (2001p.) [6]. Подальші ії роботи «Фрактальная психология. Доглубинные основания индивидуальной и социетальной 
жизни» (2005 р.) та «Архетиповий менеджмент»: монографія (2012 р.) справили великий вплив на розвиток архетипного підходу в українській гуманітарній науці.

Те, що архетипний підхід має перспективу залучення і до арсеналу соціальної філософії, ілюструє тематика науково-методичних семінарів «Української школи архетипіки» (темами міжнародних зустрічей на семінарах «УША» були «Виклики і ризики суспільної трансформації» (2016); «Громадська самоорганізація, соціальна мобільність, суспільна інтеграція» (2015); «Об'єктивне і суб'єктивне, свідоме і несвідоме у процесах соціальної інтеграції та диференціації» (2011 р.) тощо [17]. Навіть коли йдеться про звичне поєднання у єдиному методологічному конструкті «архетипу» та «міфу», то й тут не можна оминути соціального аспекту [21]. Відзначення ролі соціальної міфології у розвитку соціальної свідомості вказує на важливість розробки архетипного підходу у напрямку вирішення соціальних проблем. Не менш вагомим $є$ й аспект методологічного плюралізму, який експлуатується дослідниками різних галузей науки. Так, російська дослідниця Є. Щепановська, використовуючи в якості методологічного інструментарію «1) образно-ассоциативный; 2) генетический; 3) функционально-исторический; 4) психоаналитический, 5) структурно-семиотический и 6) аксиологический подходы к описанию мифологического мышления», формулює концепцію «базових архетипів міфології», співвідносячи їх із символами божества. Зокрема, вона послуговується аксіологічним методом виявлення генезису архетипового ядра шляхом зведення кількох міфологем до одного архетипу. Вона виводить генетичну модель, «которая дополнена до 12-ти фаз, где этапы формирования образов и идей мифологического сознания соотнесены с єтапами антропогенеза и социально-исторического развития» [22]. Таким чином, вона продовжує тенденцію до міждисциплінарності наукового дискурсу архетипу, яка має значну сучасну традицію і в українській гуманітаристиці [15].

Перспективним є напрям історико-філософських досліджень архетипу. Так, Н. Ковтун у кандидатській дисертації 2008 р. досліджує архетип культурного героя, дотримуючись «трихотомічної соціокультурної моделі діяльності міфічного героя (захисна, креативна і сакральна функція)». Дослідниця зазначає: «З точки зору історикофілософської ретроспективи архетип слід розуміти як універсальну позачасову інформаційно-енергетичну форму існування й ретрансляції духовної традиції» [8].

Результати дослідження. За визнанням О. Колчанової, «спектр интерпретаций категории «архетип» в современном культурфилософском знании широк: в русле натурализма архетип - биологический феномен, соотносимый с инстинктом; в герменевтике - первосмысл, исходное значение текста; в постпозитивизме - тип научного мышления, модель научного познания; в феноменологии - трансцендентальная схема, интенция; в прагматизме - инструмент приспособления к окружающей среде, способ оптимизации действий; в аксиологии - ценностная доминанта, обеспечивающая преемственность, единство и многообразие культурного развития; в структурном функционализме - институт, созданный обществом в ответ на необходимость удовлетворения базовых потребностей; в структурализме (постструктурализме - базовая структура, структурный фундамент культуры; в эволюционизме (неоэволюционизме) эволюционно отложенный в бессознательном древний комплекс, социокультурная универсалия; в культурно-историческом подходе - уникальное основание той или иной локальной культуры; в теории самоорганизации (синергетике) - тенденция, соотносимая с понятием «аттрактор», алгоритм мироустройства, выступающий в качестве системообразующего фактора» [9]. Деякі з цих тлумачень мають виразне соціальне значення, деякі розпочинають своє сходження до пластів соціального з вершин абстрактного трансцендентного, деякі піднімаються до осягнення соціального 3 глибин індивідуальної психіки. Але всі вони так чи інакше, раніше чи пізніше зустрічаються у соціальному, оскільки лише соціальне досі лишається єдиним надійним полем верифікації філософського смислу. «Щастя», «успіх», «досягнення», «цінність» мають значення лише як кореляти загальнолюдського та індивідуально-особистісного, зважуються у порівнянні, конструюються у сценаріях соціальних взаємодій, у параметрах 
«життєвих історій», в яких типовість, повторюваність, традиційність і тенденційність слугують маркерами вкоріненості, глибинності, регульованості процесів життєдіяльності.

В усіх перелічених концепціях саме регуляторами виступають архетипи - в яких би термінах чи категоріях ця характеристика регулятивності не описувалась - «база», «схема», «матриця», «основа», «інваріант». Сучасний архетипний підхід - це визнання слабкості раціональної нормативно-правової регуляції чи дисгармонії виключно матеріально детермінованої соціальної діяльності, аж до шкоди іiї для повноцінної самоідентифікації особи. Недарма дослідники «УША» підкреслюють різницю між «соціальною психікою» та «соцієтальною психікою» як такими, що орієнтовані амбівалентно: як схильність до зовнішньої інтегрованості у соціальні структури та як орієнтацію «на себе», на власне унікальне «Я» [6]. Розквіт практик створення «аватарів» із підміною своєї реальної особи фантастичними персонажами підкреслює тенденції до зміни самоідентифікації не на рівні окремих осіб, а на рівні суспільної (колективної) свідомості (або підсвідомості). Архетипний підхід в умовах глобалізації, мультикультуралізму та віртуалізації соціальних процесів - це передусім усвідомлення необхідності знаходження нових форм і способів збереження залишків традиційних соціальних структур (інститутів) задля безболісного подальшого розвитку суспільств. Другим завданням, яке можна розв'язати з позицій архетипного підходу, є формування нової системи соціальних практик, в якій нові форми зайнятості адекватно заповнять «дірки», що утворилися при руйнації старих професійно-статусних структур.

3 одного боку, архетипний підхід готовий виконати місію підтримки людини, що втратила соціальні орієнтири, оскільки навіть післяюнгіанська традиція архетипного аналізу налічує 100 років - досвід накопичено чималий. 3 іншого - термінологічні колізії з визначенням самого архетипу та «суміжних термінів» не додають цьому аналізу концептуальності. Деякі визначення, значно ускладнюють завдання концептуалізації термінології архетипного підходу. Наприклад «In literature, an archetype is a typical character, an action, or a situation that seems to represent universal patterns of human nature. An archetype, also known as «universal symbol», may be a character, a theme, a symbol, or even a setting» (A. M. - «У літературі архетип - це типовий персонаж, дія чи ситуація, яка, здається, являє собою універсальні зразки людської природи. Архетип, також відомий як «універсальний символ», може бути характером, темою, символом, або навіть постановкою (настройкою, настановою)» [13]. Тому максимальний практичний ефект такого підходу і досі демонструє найчастіше сфера брендінгу [16]. Дослідники розрізняють «психологічні архетипи», «літературні архетипи», «культурні архетипи», «соціальні архетипи», «етнічні архетипи», «комунікативні архетипи» тощо, при цьому відносячи одні і ті самі архетипи до різних категорій. В науках про культуру були сформовані термінологічні конструкції, похідні від терміна «архетип»: «архетипний образ», «архетипний мотив», «архетипний метод», «архетип глобальності», «архетипологія», «архетип ідентифікації», «архетип диференціації», «архетип підпорядкування» та інші. О. Донченко та Ю. Романенко постулюють архетипи як «дві моделі, які можуть претендувати на звання фрактальних архетипових форм психосоціального життя. Одна модель - упорядковувального архетипу політичного несвідомого... друга модель - соцієтальної психіки», які є двома шарами одного фрактального універсального архетипу психосоціальної природи людства» [6, c. 101]. Вони виділяють і інші концепти, наприклад, «фрактальний архетип» [6, с. 27], «архетипи дистресового досвіду» [6, с. 153]. Т. Купцова виділяє як базові «фемінінний» та «маскулінний» архетипи: «Архетипи аніми та анімусу як чуттєво сприйнята духовно-онтологічна трансцендентна реальність, будучи психологічно іманентною реальністю, являлися відображенням у людській душі об'єктивно існуючих структур буття, поєднанням реального та ідеального, космічного та психічного. У структурі міфологічної свідомості вони існували як неусвідомлені, але визначальні по відношенню до матеріального світу прафеномени буття. Вони продовжують впливати на сучасний культурний побут українців часто у формі стереотипних уявлень про фемінінне та маскулінне» [11, с. 82]. 
Наведемо повністю цитату з роботи О. Колчанової, щоб не розривати їі змісту, який ілюструє декілька аспектів нашої теми - і їі розробленість, і характеристику основних змістових положень. Дослідниця констатує, що «в работах этнологических учений понятие «архетип» служит инструментом исследования мифологии (К. Кереньи, Э. Нойман, Ш. Бодуэн, Дж. Кемпбелл). Представители ритуально-мифологической школы (М. Бодкин, Н. Фрай, К. Вейзингер, Дж. Викери) выработали специфическую практику анализа художественного текста, рассматривая произведение с точки зрения использованных автором ритуально-мифологических схем и архетипических образов. Понятие «архетипический мотив» было введено А. Н. Веселовским и определялось как «простейшая повествовательная единица, образно ответившая на запросы первобытного ума или бытового наблюдения». Кроме того, в работе Е. М. Мелетинского «О литературных архетипах» содержатся определения понятий «литературный архетип» и «архетипический мотив». В. М. Розин понятием «архетип» характеризует первооснову культуры, определяющую ее преемственность. А. А. Веремьев понятие «архетип» сравнивает с понятием «менталитет» и делает вывод, что, несмотря на соответствующие между менталитетом и архетипом различия, их содержание в значительной степени совпадает. М.К. Мамардашвили считает, что архетипы могут быть также отнесены к роду особых «понимательных вещей» (cosa mentale), орудий ума, которые, обладая всего лишь квазисуществованием, открывают человеку новые возможности духовно-практической деятельности» [9]. Іншими «робочими поняттями» архетипного підходу є концепти «архетипного образу» та «архетипного сенсу», розгляду яких присвячено багато праць. Т. Шестопалова, використовуючи визначення В. Бакусєва та К. Кереньї, стверджує, що архетипний образ можна визначити як «потенційну, меональну єдність буття та знаку, про що свідчить множинність, варіативність, i, отже, випадковість конкретних форм, яких вона набуває», а також, що «логічним продовженням розвитку архетипного образу по горизонталі виступає міфологема. Вона зафіксовує синтагматичний план розвитку архетипного образу і функціонує як відсилання до міфу, ремінісценція чи уламок останнього. Міфологемі притаманний оповідний характер та смислотворча, етіологічна функція. Сфера дії міфологеми - проміжна. Як архетипний образ, вона зберігає здатність існувати у множинній варіативності, що дає широкі можливості для інтерпретації. Як структурний компонент міфу, вона сигналізує про здатність останнього творити духовно зримий універсум» [21, с. 38]. Враховуючи, що і як «оповідання», і як «історія», міф несе функцію відтворення і творення соціокультурного простору, то методологічний потенціал концепту «архетип» для соціально-філософського аналізу стає очевидним.

Таким чином, смисл концептуалізації та використання у гуманітарній науці архетипного підходу полягає у зручності залучення в його межах термінології, орієнтованої на художнє, а не на суто технічне мислення - на «софію», а не на «епістему». Гуманістична психологія, звертаючись до екзистенціалів людського буття, прагнула встановити систему категорій, в яких воно відображалося б цілісно, у повноті духовно-душевно-соціально-тілесних, а не лише соціальних чи лише тілесних проявів. Саме тому у методологічних моделях гуманістичної філософії $є$ місце поняттям «творчості», «фантазії», «смислу», «самості». Свідомо вибудовуючи ланцюжок сенсів «мистецтво - архетип - міф - міфотворчість», К. -Г. Юнг парадоксальним чином поєднує «безликість», абстрактність архетипу з його виразною культурною денотацією: «Архетип обов'язково образ і емоція... Це шматки самого життя, котрі через емоції пов'язані з живою людиною» (цит. за Я. Коршуновою) [10, с. 49]. 3 іншого боку, «емоція» та «екзистенціал» - це самостійні поняття, утверджені в науковій літературі. I коли у текстах зустрічаються згадки про «архетип любові», «архетип страху», то можна заперечити, що дані поняття відображають передусім саме психологічні, суб'єктивні стани окремої особи, викликані різноманітними чинниками, і ніякі вказівки на те, що «скеровуючими силами постає «індивідуальна свідомість» як певної індивідуальності, так і свідомість певної етнокультури [10, с. 49], не захищають від «метафізичної» критики за ототожнення понять і творення на вже зайнятому місці зайвого методологічного 
«нашарування». Йдучи за таким принципом, можна оголосити «архетипом» все, що стосується людського буття, всі його нюанси і пласти. У результаті даного неправомірного ототожнення доля людства чи соціальних колективів ставиться в залежність від екзистенційного «почування» індивіда, що очолює структуру, і виправдовується «іманентністю» та «інваріантністю» його приватних рішень, продиктованих архетипом, скажімо, ненависті. Адже «за К. -Г. Юнгом, архетипи - суть автономні, незалежні від людської волі феномени колективного несвідомого, які спонтанно - згідно зі своїми внутрішніми законами - впорядковують і вибудовують психічні елементи в певні архетипові структури... Невід'ємні властивості - автономність і неусвідомлюваність, нумінозність (тобто відчуття надособистісного, трансцендентного характеру), висока емоційна потенція» [12, с. 265-266]. І хоча історія диктатур наглядно показує роль особистості Провідника нації і механізми тоталізації мімікрії у суспільних настроях залежно від «психічного образу» Керівника структури, все ж цей підхід позбавляє суспільства надії на власний вибір шляху (опозицію як символ архетипу спротиву), а країни - на крос-культурний діалог та соціальний розвиток. Якщо архетип є сценарієм емоційного диктату і раз і назавжди встановленою даністю, то людська історія повністю підпорядковується моделі Володаря як виразника Волі Неба і зупиняється у своєму демократичному (плюралістичному) розвитку. Таким чином, політика перетворюється на містику, а її ключовою особою неодмінно стає Великий Інквізитор.

Із проблематикою емоційності як дискусійної риси архетипу пов'язано нечітке розмежування архетипу, стереотипу, паттерну (установки), цінності, символу тощо. Детальніше про останню кореляцію розповідає I. Процик [19]. Архетип, що позначає (або транслює) емоцію, набуває переважно предметно-речового (або топонімічного, артефактного втілення), або втілення в усій сукупності духовної культури.

До ментальних конструкцій архетипів предметно-речового рівня можна віднести архетипи стихій - «Вода», «Вогонь», «Повітря», «Земля» [3]; до архетипів рівня культурних універсалій - «архетипи етичної цінності вільної особистості», «архетип слова», «архетип серця» [7]. Водночас тема «персоніфікації архетипу» в образі веде за собою явну диференціацію в їх «таборі» на архетипи, які мають виразне фігуральне звучання (втілюються у персоніфікованих образах), та архетипи, що мають виразне процесуальне спрямування. Іноді дослідники не диференціюють їх за даними категоріями, обмежуючись переліком. Так, серед архетипів Н. Лисюк зазначає ті, що «центрують відповідно до психічних механізмів структури людської особистості (Персона, Тінь, Аніма / Анімус, Самість), магістральних шляхів розвитку і становлення людини, насамперед процесу індивідуації (архетипи зачаття, зародкового розвитку із супутнім океанічно-острівним комплексом, - пор. пренатальну теорію Ф. Б. Я. Кейпера, архетипи розділення «я», капітуляції, містичної подорожі, боротьби із суперником i перемоги над ним, знаходження скарбу і визволення аніми-полонянки, священного шлюбу, трансформації і відродження), відповідно до ііі родових інтуїцій (Велика Матір, страшний Батько, Вічне Дитя, Діва) та інстинктів суперництва-агресії (трікстер, Звір), зрештою трансцендентних (божественних) устремлінь (Старий Мудрець психопомп) [14, с. 266]. Ми бачимо тут і фігуративний, i процесуальний аспект архетипу. Інші дослідники дотримуються «чистоти класифікації». Так, М. Дідух наводить авторську схему «Співвідношення етнічних стереотипів, етнокультурних архетипів та персонажів народної свідомості», в якій співвідносить, до прикладу, класичний юнгіанський архетип Анімуса із чоловічим гендерним стереотипом, що втілюється в українській культурі у Персонажі Козака, селянина; в етнокультурному архетипі Мудрого Старця вбачає елемент стереотипізації сімейних ролей, персоніфікований образом Кобзаря і т. ін. (фігуративний аспект архетипу з акцентом на персоніфікації в образі людини) [4]. Натомість О. Донченко, яка у статті «Архетипи - спільне в нашому житті (розпізнавання архетипів як шлях до унікальності)» стверджує, що «в широкому інформаційному дискурсі архетипами тепер називають універсальні способи організації індивідуального людського досвіду» [5, с. 170], виділяє спільно з Ю. Романенком 15 архетипів візантійського менталітету, чітко розташовуючи їх у логічній послідовності: 
«1. Архетип «вічного учня». II. Архетип «героїзованого злочинця». III. Архетип домінування уречевленого (ситуації, минулого) над процесуальним (мотивацією, майбутнім). IV. Архетип об'єктивно-речової детермінації буття. V. Архетип обрядності та імітативності. VI. Архетип «вічного повернення». VII. Архетип едукативності психокультури. VIII. Архетип анігілятивної рівності. IX. Архетип долі. Х. Архетип ідеалізації старовини. XI. Архетип тотожності істини і влади. ХІІ. Архетип центрованої провини. XIII. Архетип монарності буття. XIV Архетип «вічної правди». XV. Архетип звеличення юродивого» [6, с. 170-171]. Очевидно, що тут йдеться саме про підгрунтя соціальної практики, про соціальну психологію із потенційним виходом у соціальну філософію, а не у культурологію чи етнопсихологію. На нашу думку, саме цей аспект архетипного підходу потребує подальшого унормування, або віднесення «фігуративних» архетипів до образів (тоді увиразнюється роль символу), а до категорії архетипів слід віднести ті складові детермінації людської діяльності, які, будучи і досі «замкненими» у сфері антропології та теорії культури, не мають адекватного виходу у методологію соціальної філософії. Йдеться про сутнісні сили людини - «дух», «душа», «розум», «розсудок», «воля», «тіло» - архетипний вплив специфіки яких на діяльність, у тому числі соціальну, очевидний, але і досі не артикульований.

Нам видається цілком правильним також дослідницьке завдання, яке поставив 2008 року російський автор А. Левіч у статті «Язык категорий и функторов как архетип количественного и динамического описания Мира», присвятивши її «поиску языка для описания теоретического знания: 1) предоставляющего архетип видения Мира как процесса, а не объекта; 2) достаточно универсального для применения в междисциплинарном знании; 3) достаточно строгого для возможности формализации знания и 4) позволяющего эксплицировать базовые общенаучные понятия» [12, с. 25]. Не менш актуальним у контексті розвитку метамови сучасної філософії в умовах некласичної раціональності є робота також російського дослідника Д. Анкіна «Архетипы философского дискурса», в якій «возможные, согласно получаемым знаковым моделям, типы философского дискурса интерпретируются в качестве архетипов философствования, а их семантика - в качестве трансцендентальной семантики» $[1$, c. 22].

Отже, архетип не є ні принципом, ні правилом, ні установкою [14, с. 264]. Його також не слід ототожнювати із символами або образами. Разом з тим можливо - саме через цю генетичну зв'язаність архетипу із «суміжними поняттями» - встановити механізм їх взаємовідношення. Так, «якщо архетип - це досвід поколінь, багатовікове переживання певних уявлень, умов життя, то саме цей видозмінений, усвідомлений зміст $є$ основою образотворення у творчій діяльності. Виявами архетипу є символ, образ, міф, зазнаючи видозмін у фольклорній, літературній, образотворчій діяльності, але не втрачаючи зв'язок з ним» [10, с. 49]. Отже, архетип є абстрактним творчим субстратом для формування матеріальних чи мовних фігуративних «виробів», матеріалом для наступного надання форми за допомогою образу чи символу, задумом для подальшого конструювання дискурсу (оповідання, міфу), смислом-змістом та смислом-підставою для створення форми (Б. Путилов). Тут-таки постає нова перепона до концептуалізації поняття «архетипу», а саме - небезпечне зближення його із поняттям «ідея». Підстави такого ототожнення пояснює Н. Ковтун: «Розвиток будь-якої історичної епохи базується на типових константах духовного життя людської спільноти, котрі у різних філософських концепціях дістали відмінні назви: «архетипи», «праобрази», «універсалії», «інваріанти», «форми без змісту», «наскрізні інформаційно-енергетичні структури». У західній філософській традиції ідея праобразів-архетипів була висловлена Платоном, за вченням якого первинний світ ідей тотожний світові праобразів, котрі шляхом еманації втілюються у матеріальному світі» [8]. Детальніше про смислові конотації понять «архетип» та «ідея» можна прочитати у роботі «Поняття архетипу в науковій літературі: генетико-теоретичний аспект» I. Процик, де Платон, Філон Олександрійський, Філон Іудей, Іриній, Діонісій Ареопагіт, Августин Блаженний згадуються як такі, хто стояв біля витоків теорії міфу та розвивав архетипні уявлення 
(сам архетип називається дослідницею «складовою ланкою у процесі міфотворчості») [20, с. 56]. За твердженням Н. Лисюк, «підсвідомо фольклористи та міфологи відчувають недостатність таких одиниць, як універсалія, з одного боку, та інваріант - 3 іншого, розуміють, що вони не охоплюють повністю весь той матеріал, що його доводиться досліджувати i, певною мірою, спонтанно прагнуть вживати поняття «архетип» для означення одиниці якогось вищого, більш інтегрального рівня $[14$, с. 265$)$. Так що фактично поняття «праобраз», яке передається з джерела до джерела при виконанні завдання категоризації ознак поняття «архетип», відображає смисл «всезагальної, універсальної основи».

Висновки. Отже, намагаючись співвіднести і скоординувати пістрявий методологічний інструментарій та категоріальний апарат архетипного підходу, необхідно дотримуватися принципу «відображення відображення» (як у галереї дзеркал). У соціально-філософському ж контексті категоріальний апарат архетипного підходу, багатий на можливості діалектичного узгодження смислів, дає перспективи розгляду (або перегляду) не лише усталених структурно-функціональних моделей, але і аналізу нових, характерних для постіндустріальних інформаційних суспільств проблем, пов'язаних із, наприклад, новими сферами соціальної діяльності. Адже «аналіз архетипів, як стверджував С. Кримський, становить досить адекватний метод дослідження менталітету, праісторії та майбутнього суспільних утворень» [6, с. 27].

\section{REFERENCES}

1. Ankyn, D. V. (2003). Arkhetypy filosofskogo deskursa [Archetypes of philosophical discourse] Izvestiya Urals'kogo gosudarstvennogo universiteta. № 27, s. 22-23 (in Russian).

2. Arkhetyp (2002). Filosofs 'kyy entsyklopedychnyy slovnyk. Institut filosofiyi im. H. S. Skovorody NANU. K.: Abrys, 744 s. (in Ukrainian).

3. Hryn'ko, O. S. (2013). Kontsepty-arkhetypu v prozi V. Holdinha [Concepts-archetypes in the prose of V. Golding]: avtoref. dys... kand. filol. nauk: 10.02.04. Odessa Nats. Un-t im. S. S. Mechnikova; 20 s. (in Ukrainian).

4. Didukh, M. L. (2011). Kategoryzaciya ponyattya etnichnogo arkhetypu ta problema jogo vidmezhuvannya vid etnichnogo stereotypu [Categorization of the concept of ethnic archetype and the problem of its separation from ethnic stereotype]. Visny'k Nacional'noyi akademiyi Derzhavnoyi pry'kordonnoyi sluzhby'Ukrayiny'. Vy'p. 4. URL: http://nbuv.gov.ua/UJRN/ Vnadps_2011_4_32 (in Ukrainian).

5. Donchenko, O. (2011). Arkhetypy' - spil'ne v nashomu zhy'tti (rozpiznavannya arkhetypiv yak shlyakh do unikal'nosti) [Archetypes - common in our lives (recognition of archetypes as a way to uniqueness)]. Psykhologiya osobystosti. № 1, s. 170-181 (in Ukrainian).

6. Donchenko, O., Romanenko, Yu. (2001). Arkhetypy'social'nogo zhy'ttya i polityka (Glybynni regulyat'yvy psykhopolitychnogo povsyakdennya) [Archetypes of social life and politics (Deep regulations of psychopolitical everyday life)]: Monografiya. K.: Lybid', 334 s. (in Ukrainian).

7. Koval'chuk, N. D. (2016). Arkhetyp sofijnosti v konteksti tvorchogo dorobku Pavla Tychy'ny [The archetype of sophistry in the context of the creative work of Pavel Tychyna]. 'Naukovy'j visny'k Nacional 'nogo universy'tetu bioresursiv i pryrodokorystuvannya Ukrayiny'. Seriya: Filologichni nauky', Vy'p. 248, s. 103-109 (in Ukrainian).

8. Kovtun, N. M. (2007). Arkhetyp kul'turnogo geroya v ukrayins'kij dukhovnij tradyciyi: istory'kofilosofs'ky'j kontekst [The archetype of a cultural hero in the Ukrainian spiritual tradition: historical and philosophical context]. Dysertaciya na zdobuttya naukovogo stupenya kandydata filosofs'kykh nauk za special'nistyu 09.00.05 - istoriya filosofiyi. Kyyivs'kyj nacional'nyj universytet imeni Tarasa Shevchenka. Kyyiv, Rezhy'm dostupu: http://library.nuft.edu.ua/ebook/ file/09.00.05knmifk.pdf (In Ukrainian).

9. Kolchanova, E. A. (2006). «Arkhetyp» kak kategoryya filosofyy' kul'tury [«Archetype» as a category of philosophy of culture]: dyssertacyya ... kandydata filosofskykh nauk: 24.00.01. Tyumen', 160 s. (In Russian).

10. Korshunova, Ya. I. (2017). Znachennya arkhetypu u procesi khudozhn'oyi tvorchosti'[The value of the archetype in the process of artistic creativity]. Teoriya i praktyka suchasnoyi nauky'. Materialy' II Mizhnarodnoyi naukovo-praktychnoyi konferenciyi (m. Chernivci. 24-25 
lystopada2017 roku). U2-x chastynakh. Kherson: Vydavnychyj dim «Gel’vetyka», Ch. 1, s. 49-51 (in Ukrainian).

11. Kuptsova, T. A. (2014). The feminine and masculine archetypes in the structure of a pagon myth. Anthropological Measurements of Philosohical Research. № 5, pp 77-83. (in English).

12. Levy'ch, A. P. (2008). Yazyk kategoryj y funktorov kak arkhetyp kolychestvennogo y dynamycheskogo opysanyya Myra) [Language of categories and functors as an archetype of quantitative and dynamic description of the World]. Systemy y'modely': granyczy interpretacyj. Tomsk: Yzd-vo Tomskogo gosudarstvennogo pedagogycheskogo unyversyteta, s. 25-33 (in Russian).

13. Literary Devices. Definition and Examples of Literary Terms. LiteraryDevices Editors. «Archetype» LiteraryDevices.net. 2020. Web. 6 july. 2020. URL: hhtp//literarydevices.net/ archetype/ (in English).

14. Ly'syuk, $N$. (2001). Ponyattya arkhetypu v narodnij kul'turi [The concept of archetype in folk culture]. Dukh i litera. № 7-8, s. 262-276 (in Ukrainian).

15. Makarova, A.O. (2020). Arkhetyp yak predmet doslidzhen' u suchasnij ukrayins'kij gumanitarystyci [Archetype as a subject of research in modern Ukrainian humanities]. Gileya: naukovyj visnyk. K.: «Vydavnycztvo «Gileya», Vyp. 152 (№ 1), s. 171-176 (in Ukrainian).

16. Makarova, A. O. (2020) Archetypical approach to activity: legitimation by practice. SKHID. Analytic and informative journal. No. 1 (165) January-February, pp. 75-81. (in English).

17. Makarova, A.O. (2020). Arkhetypnyj pidkhid u suchasnykh ukrayins'kykh doslidzhennyakh social'noyi diyal'nosti: dosvid ukrayins'koyi shkoly arxetypiky' [Archetypal approach in modern Ukrainian studies of social activity: the experience of the Ukrainian school of archetypes]. Gumanitarni viziyi. Tom 6, \# 1, s. 54-59 (in Ukrainian).

18. Proekty' shkoly [School projects]'. Sajt «Ukrayins'koyi shkoly arxetypiky'». URL: https://usarch. $\operatorname{org} / \# /$

19. Procy'k, I. V. (2011). Arkhetyp i symvol: problemy vyznachennya ta vzayemodiyi [Archetype and symbol: problems of definition and interaction]. Aktual'ni problemy slov'yans 'koyi filologiyi. Seriya: Lingvistyka i literaturoznavstvo: Mizhvuz. zb. nauk. st. Vy'p. XXIV, ch. 2, s. 368-377 (in Ukrainian).

20. Procy'k, I. V. (2009). Ponyattya arkhetypu v naukovij literaturi: genetyko-teoretychnyj aspekt [The concept of archetype in scientific literature: genetic and theoretical aspect]. Visny'k ZNU. Ser.: Filologichni nauky. Zaporizh ғ 2, s. 56-67. (in Ukrainian).

21. Shestopalova, T. (1999). Korelyaciya ponyat' «arkhetypnyj obraz-mifologema-symvol-mif»: (na prykladi poeziyi P. Tychyny) [Correlation of concepts «archetypal image-mythologemesymbol-myth»: (on the example of poetry of P. Tychyna)]. Naukovi zapy'sky'NaUKMA. T. 17: Filologiya, s. 37-41 (in Ukrainian).

22. Shhepanovskaya, E. M. (2011). Genezys y klassyfykacyya myfologycheskykh arkhetypov: kul'turfilosofskyj podkhod [Genesis and classification of mythological archetypes: a culturalphilosophical campaign]. Avteref. dyss. na soyskanye uch. stepeny kand. filos. nauk. Specyal'nost' 09.00.13 - filosofskaya antropologyya, filosofyya kul'tury. Sankt-Peterburg. Rezhym dostupu: http://cheloveknauka.com/genezis-i-klassifikatsiya-mifologicheskih-arhetipov (in Russian).

Received 18.08.2020

Received in revised for 12.10 .2020

Accepted 18.10.2020 